\title{
Fingerprint, Monitoring and Work Discipline of Indonesian Public Servants: Evidence from Kepulauan Riau
}

\author{
Wayu Eko Yudiatmaja ${ }^{1}$, Tri Samnuzulsari ${ }^{1}$, Alfiandri $^{1} \&$ Surya Mahdalena ${ }^{1}$ \\ ${ }^{1}$ Universitas Maritim Raja Ali Haji, Indonesia \\ Correspondence: Wayu Eko Yudiatmaja, Department of Public Administration, Faculty of Social and Political \\ Sciences, Universitas Maritim Raja Ali Haji, Tanjungpinang, Kepulauan Riau, 29124 Indonesia. Email: \\ wayuguci@umrah.ac.id
}

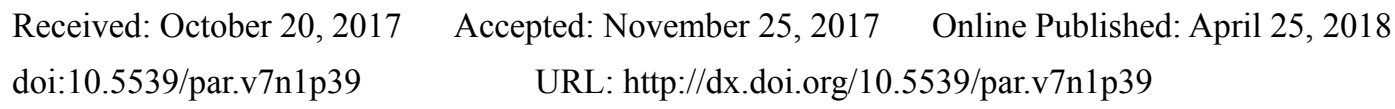

\begin{abstract}
Recently, there are many public organizations in Indonesia use fingerprint to controll the attendance of the employee. However, the effectiveness of the implementation of this system has never been evaluated. This research aims at examining the influence of the using fingerprint and monitoring on work discipline of the employees in vertical organizations below the Ministry of Education and Culture of Republic of Indonesia in Kepulauan Riau. 44 public employees from the Board of Cultural Preservation and Language Office have been participated in this study. Using multiple linear regression, this study reveals that the using of fingerprint and monitoring have significant influence on work discipline simultanoeusly. Monitoring has positive influence on work discipline. Meanwhile, implementation of fingerprint has not influence on work discipline. Through this study, authors deny the perception of many policy makers in Indonesia and prior scholars that fingerprint can increase the discipline of public servants.
\end{abstract}

Keywords: fingerprint, monitoring, work discipline, public servants

\section{Introduction}

After the movement of bureaucratic reform, there is a fundamental change in Indonesian public sector. One of the agenda of bureaucratic reform applied is to make use of development of information, communication, and technology adopting various media of communication and information to serve public sector activities. This idea is drived by the reason that the use of ICT has long been believed to improve the quality of governance and delivering public services (Singh et al., 2010; Yudiatmaja \& Yoserizal, 2010; Giné et al., 2012). The use of ICT in supporting government tasks can not be separated from the efforts to pursue the efficiency and effectiveness of governance. As the principles of contemporary public management, the public sector is encouraged to use all resources possessed efficiently and accountably, and can utilize them effectively to achieve maximum performance (Osborne \& Gaebler, 1992; Kettl, 2000).

One of the technology adopted by Indonesian public sector is fingerprint. The fingerprint is used to improve the discipline of the employee because this technology can contribute in recording the presence of the employees in the office (Jain et al., 1997; Saraswat \& Kumar, 2010; Shoewu \& Idowu, 2012). This technology replaces the recording manual attendance system because the old system is not able to verify the presence and return of the employees accurately. In addition, manual absence is prone to manipulative behavior by the employees so it can not be used as an objective instrument to measure the discipline of the employee. These weaknesses are tried to be covered by using fingerprint. Until now, almost all public organizations in Indonesia have used the fingerprint system. As the result, the system generates a dramatic change. The survey conducted by McKenzie et al. (2014) showed that the use of fingerprint has reduced the rate of teacher absenteeism in Indonesia's public schools from 19 percent to 9.8 percent between 2003 and 2014.

Discipline has long been the most critical point of all organizations. This happens because the discipline plays a significant role in achieving organizational goals (Belohlav, 1985; Riccucci \& Wheeler, 1987; Redeker, 1989; Hays, 1995). Discipline is one of the function of management which relieves the organizations to stay on the track to achieve their goals. Without high discipline almost certainly, organizational goals will not be reached effectively (Robbins \& Judge, 1993; Harrald, 2006). Therefore, managers are required to maintain the stability of individual, team work, and organizational discipline so the organizational goals can be achieved well. Although 
this responsibility entirely exists with the manager, but if it is not supported by every organizational component, such as subordinates, systems, and rules, it is impossible for discipline to be attained.

The design and implementation of disciplinary policies in public organizations are believed to increase the commitment and performance of the employees (Beyer \& Trice, 1984; Leavitt \& Johnson, 1998; Franklin \& Pagan, 2006). Various efforts are performed by policy makers to formulate the systems and rules improving the discipline of the employee. Some discipline methods are applied with slightly rules. There are also just applying the general rules relating to discipline. Finally, there are also using mechanical methods in applying employee discipline. The latter method utilizes technology as a tool to evade the discipline of the employee. However, most scholars believe that transformational and problem-oriented leadership is more likely to succeed than the leaders using a punitive approach in creating the discipline of the employee (Huberman, 1964; Grote \& Harvey, 1983; Manthey, 1993; Senge, 1997; Grote, 2006).

In Indonesian public sector, there are several contemporary studies on the use of fingerprint and its relation to the discipline of the employee (McKenzie et al., 2014; Asmira, 2016; Anggara, 2016). There are also studies revealing that the work discipline affects the employees performance significantly (Soss, Fording, \& Schram, 2011; Thaief, Baharuddin, \& Idrus, 2015; Sofyan et al., 2016). In addition, there are also studies finding that discipline punishment is determined by status, talent, compensation, and performance factors (Rosen \& Jerdee, 1974). Meanwhile, this study not only exercises the use of fingerprint in the context of Indonesian public sector, but also the monitoring of supervisors and its influence on the discipline of the employee. This is inseparable from the argument that monitoring is one of the most critical functions of management in creating an order and discipline of employees (Terry \& Franklin, 1968; Taylor, 2003; Drucker \& Maciariello, 2008). Therefore, beside the variable of fingerprint, it is necessary to examine how much the influence of monitoring by the supervisors on employee discipline.

\section{Theoretical Review}

\subsection{The Influence of Fingerprint on Work Discipline}

The strengthening of discipline and supervision of subordinates is the managers responsibility. In its practice in the public sector, the implementation of this function is not as easy as in the private sector (Guffey \& Helms, 2001; Hays, 2008). Basically, the public sector has some quite fundamental differences compared to the private sector (Murray, 1975; Rainey, Backoff, \& Levine, 1976; Lachman, 1985; Rainey \& Bozeman, 2000; Boyne, 2002; Rainey, 2003; Meier \& O'Toole, 2011). One of the major differences in disciplinary and monitoring is that the public sector relies heavily on obsolete and rigid regulations. The existing rules are sometimes not accommodative to the developments and the dynamics occuring in the field. As a result, public sector managers often have a personal dilemma in monitoring and enforcing discipline against their subordinates.

Conceptually, the discipline has a large meaning. Edwards \& Scullion (1982: 322) argues that sociologically, discipline can be interpreted as, "behaviour as a socially significant forms of rule-breaking". Whereas in organizational perspective, according to Hays (2008: 555) discipline is, "compromise the human resource management processes by which organization seek to correct deviations from acceptable conduct, and to rid themselves of individuals who are unable or unwilling to comply with reasonable standards of performance". According to Guffey \& Helms (2001: 112) discipline is, "control gained by enforced obedience". Thus, it can be said that discipline is not just a matter of imposing sanctions, but also in the form of corrective action against various errors or deviations occuring.

In its development, discipline enforcement is divided into two approaches, namely punitive and non-punitive approach (Huberman, 1964; Grote \& Harvey, 1983; Bryant, 1984; Campbell, Fleming, \& Grote, 1985). The non-punitive approach is called by Hays $(1996,2008)$ as a positive discipline approach in human resource management. Meanwhile, Guffey \& Helms (2001) reveals that there is a model of progressive discipline and positive discipline. The punitive approach in disciplinary strengthening is highly oriented towards the rewards and punishment given to subordinates. Non-punitive approach, however, suggest that disciplinary enforcement is a part of coaching, so managers should more persuasive and applying motivational methods to subordinates.

In Indonesian public sector, recent studies suggest that the work discipline affects performance of the employees. The Study of Mangkunegara \& Waris (2015) on the employees of PT Asuransi Bangun Askrida found that three variables tested - training, competence, and work discipline-work discipline variables have the greatest influence on performance of the employee partially, with the significant value of 0.621 (R2=0.62). Training valiable has an influence of $0.56(\mathrm{R} 2=0.56)$ and competency variable has an effect of $0.46(\mathrm{R} 2=0.46)$ on performance of the employee. While, the three variables affect performance of the employee of 0.648 or $64.80 \%$ simultaneously. 
The study of Mangkunegara \& Waris (2015) was confirmed by the study of Thaief et al. (2015) suggesting that training, compensation, and work discipline have a significant influence on performance of the employee of PT PLN Area Malang, both partially and simultaneously. Meanwhile, the findings of Sofyan et al. (2016) in the Regional Office of Ministry of Religious Affairs, South Sulawesi Selatan found that there is positive impact between carrier development on performance and work satisfaction of employees. However, based on the research of Sofyan et al. (2016) noted that work discipline and work satisfaction solely correlating of 0.044 (4.4\%) against performance of the employee. In other words, work discipline has not significant correlation on performance of the employee.

Some studies on implementing fingerprint and its impact on the discipline of the employee also showed a positive result. Its mean, statistically the using fingerprint has a significant effect on the discipline of the employee. The study of Asmira (2016) for instance, revealed that the use of fingerprint was highly effective in improving the discipline of the employee in Anggana District, Kutai Kartanegara Regency. Furthermore, the findings of the research suggested that recording the presence of employee using fingerprint was more effective in developing attainment of performance target. Unfortunately, the research used qualitative approach and descriptive method. This is become a weakness of the study because the findings can not justify quantitatively how significant the effectiveness of the implementation of fingerprint.

Anggara (2016) also explored the implementation of fingerprint have a significant affect on the discipline of the employee in the Faculty of Social and Political Sciences (FISIP) UIN Sunan Gunung Djati, Bandung. Using policy implementation theory by Edward III (1980), Anggara (2016) examined the significance of communication, resources, disposition, and bureaucratic structure variables on work discipline of civil services in FISIP UIN Sunan Gunung Djati. As Anggara (2016) mentioned, implementing fingerprint has a cooficient determination of 46.34 on employee discipline. Its mean, $46.34 \%$ of variable of implementing fingerprint influented the discipline of the employee, the rest $53.66 \%$ was influented by other variables. The study used Edward III (1980) conception of policy implementation in determining fingerprint variable, consists of communication, resources, disposition, and bureaucratic structure. The indicators are less precise in policy implementation studies using system or technology. Hence, in contrast to the study, the researchers engage other indicators, such as functionality, reliability, usability, and efficiency in measuring fingerprint variable.

\subsection{The Influence of Monitoring on Work Discipline}

Basically, monitoring is one of the function of management purposing to ensure that resources are collectively used towards achieving the organizational goals, by undertaking various actions are required, such as observation, control, and correction (Daft, 2008; Yukl, 2010; Robbins \& Coulter, 2012). The managers role is to conduct monitoring over their subordinates so that subordinates can work in accordance with the organizational goals and objectives. Managers responsible for providing assistance and correction in the case of errors or violations. It is important to implement so to subordinates feel that they have been interested, it is also important to create order, discipline, and constancy of subordinates action to the organizational mission. The failure of managers to supervise their subordinates will impact to the failure of achieving the organizational goals.

Some previous studies found that monitoring could increase the discipline of employees. Edwards \& Scullion (1982) investigated monitoring from supervisors extremely impact on the discipline of the employee on the labors of clothing factories. Monitoring of supervisors also has a substantial role in detracting absenteeism and turnover of employees. The findings of de Jong \& Hartog (2007) revealed that monitoring of supervisors has a prominent influence to improve work discipline and innovative behavior of employees. From the study conducted on 12 managers of small and medium enterprise in the Netherlands, de Jong \& Hartog (2007) concluded that there are 12 behaviors of leader encouraging innovation of subordinates, one of them is monitoring behavior. Thurau \& Wald (2009) suggested that monitoring of partners and supervisors influent positively and significantly on the discipline of police cadets in the police schools in Massachusetts, United States.

\subsection{The Use of Fingerprint in Indonesian Public Sector}

The identification method of human presence quantitatively is developed by Alphonse Bertillon. The method was used in the United States to identify prisoners until 1920s (Wayman, et al., 2005). The method uses Biometrics technology to book the presence of the people. Biometrics is, "the use of computers to recognize people, despite all of the across-individual similarities and within-individual variations" (Wayman et al., 2005). Biometrics is one of the branch of Biology combined with statistical data and quantitative analysis. Biometrics technology generates various identification method and verification of the human presence broadly adopted by many organizations (see Table 2.1). 
At the first time, fingerprint widely was used by private companies to detect the presence of employees. However, in 2000s it was introduced in Indonesia's government organizations. Almost all of public organizations in Indonesia have implemented Biometrics technology in identifying the presence and the return of employee from the office, mainly using fingerprint method. Throughout the development of Biometrics technology, many government agencies have left the fingerprint and switching method using retinal scans. During its development, the model of retinal scans are believed to have a degree of accuracy much better than fingerprint. The study of Hendrotriatmoko, Hadi, \& Dachlan (2014) found that the model of retinal scans have an accuracy up to $96.43 \%$ rates in identifying the presence of employees.

Table 1. Comparison of biometrics technologies

\begin{tabular}{c|c|c|c|c|c|c|c}
\hline Biometrics & Universality & Uniqueness & Permanence & Collectability & Performance & Acceptability & Circumvention \\
\hline \hline Face & high & low & medium & high & low & high & low \\
\hline Fingerprint & medium & high & high & medium & high & medium \\
\hline Hand Geometry & medium & medium & medium & high & medium & medium & medium \\
\hline Hand Vein & medium & medium & medium & medium & medium & medium & high \\
\hline Iris & high & high & high & medium & high & low \\
\hline Retinal Scan & high & high & medium & low & high & low & high \\
\hline Signature & low & low & low & high & low & high & low \\
\hline Voice Print & medium & low & low & medium & low & high & low \\
\hline \begin{tabular}{c} 
F.Thermograms \\
\hline
\end{tabular} & high & high & low & high & medium & high
\end{tabular}

Source: Jain, et al. (1997: 1366)

In Indonesian public sector, the use of fingerprint is related to the strengthening of discipline and allocation of meal allowance as possible as Regulation of Ministry of Finance No. 72/PMK.05/2016. Fingerprint is a technology which can verify accurately and accountably the presence and work time of employees during their activities in the office. Fingerprint technology totally assists the public sector managers in monitoring work discipline of their subordinates, in the dimension of the presence and work time. In accordance with Government Regulation No. 53 Year 2010 about the discipline of public servants, leaders can present punishment to the employees who are absent from work or home early based on each stage of their failures. The punishment of public servant discipline as stipulated in Government regulation No. 53 Year 2010 can be conducted, from slight to serious disciplinary punishment. The slight punishment is the direct supervisor's reprimand. The medium punishment is delay the rise of wage and position. While, the serious punishment can be formed dismissal. Fingerprint method is used also as a basic to serve meal allowance to the public servants. Refered to the Ministry of Finance affairs, the meal allowance of public servants is offered from Rp32.000,00 to Rp35.000,00 per day considering the presence of employees in one month. Data recorded by fingerprint can be utilized as a basic to the meal allowance

\subsection{Hypotheses and Conceptual Framework}

Based on the background of the problem, theoretical review and conceptual framework, hypotheses in this study are proposed as follows:

H1 : There is positive and significant influence between fingerprint and work discipline

H2 : There is positive and significant influence between monitoring by supervisors and work discipline

H3 : There is positive and significant influence of fingerprint and monitoring on work discipline simultaneously

The conceptual framework has been constructed based on hypotheses presented above regarding fingerprint, monitoring, and work discipline (see figure 1). The framework indicates that fingerprint and monitoring have both partially and simultaneously effects on work discipline of public servants. 


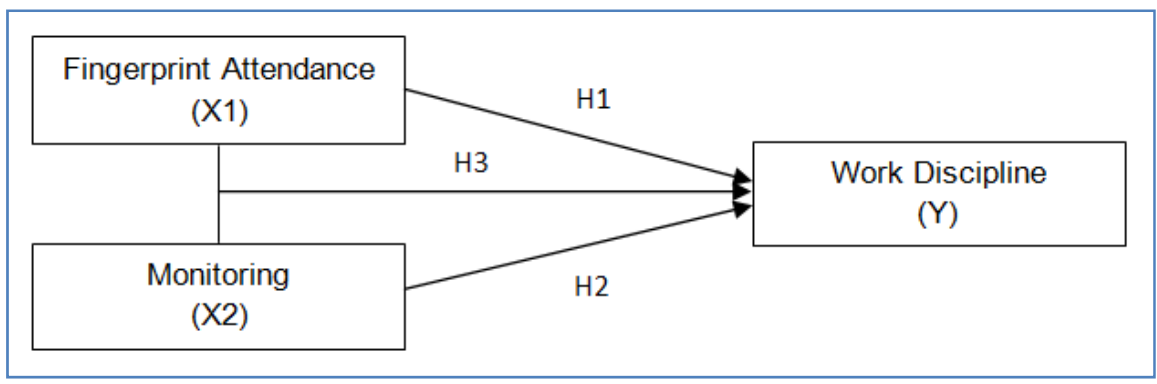

Figure 1. Conceptual framework

\section{Methods}

\subsection{Study Design and Sample Selection}

This study was conducted with survey on public servants in vertical organizations under the Ministry of Education and Culture. The population of this study derived from vertical institutions on Ministry of Education and Culture located in Riau Archipelago Province, namely the Board of Cultural Preservation and Language Office. This study used total sampling with 29 participants of the Board of Cultural Preservation and 15 participants of the Language Office. The questionnaires were written in Bahasa Indonesia. All questionnaires were administered leave-in organizations and were collected on site by one of the researchers within a 1-month period. During the data collection, the participants were allowed to end the interview if they did not wish to answer certain questions. The researcher approached 44 public servants for this study.

\subsection{Survey Instruments}

A set of questionnaires was developed to measure the constructs in this conceptual model. The three constructs were fingerprint (14 items), monitoring (10 items), and work discipline (9 items). Existing measurements for multi-item constructs which have been verified in the literature were used when possible. A 5-point Likert scale was used, ranging from 1 (strongly disagree) to 5 (strongly agree), to measure negative and positive assessments of the trait. The fingerprint instrument was adapted from the ISO 9126 quality software - functionality, reliability, usability, efficiency, maintainability, and protability - (Bevan, 1995; Bevan \& Azuma, 1997; Bevan, 1999; Al-Qutaish, 2010) with modified. The monitoring instrument measurement was adapted by Stoner, Freeman, \& Gilbert (1995). The monitoring instrument measures the perceived control of planning the standards and rules, determining implementation of activity, comparing work with routine standard, and correcting action. The work discipline instrument measures punctuality, finishing all of the work, and abiding by the rules. These instrument measure self-awareness of public servants with their respect to fingerprint, monitoring, and work discipline.

All survey instruments were discussed among researchers to obtain feedback on their validity and clarity in Indonesian context. The researchers were asked to evaluate the content validity of the questionnaire. Then, the questionnaire was tested before administered to all respondents. The survey instruments were slightly modified based on feedback from the respondents. The final questionnaire has four sections: the first section examines the demographic profiles of respondents; the second section investigates fingerprint; the third section examines monitoring by supervisors; and the final section investigates work discipline.

\subsection{Statistical Analysis}

Data analysis was conducted using multiple lineral regression with SPSS (Statistical Package for the Social Sciences) 2.1. The regression equation model used in this study is $y=\alpha_{0}+\beta_{1} x_{1}+\beta_{2} x_{2}+\varepsilon$, where: $\mathrm{y}=$ work discipline; $\alpha_{0}=$ constanta; $\beta_{1} x_{1}=$ fingerprint; $\beta_{2} x_{2}=$ monitoring; $\varepsilon=$ margin of error. Before exercising the regression analysis, the researchers assessed multicolinearity, autocorrelation, heteroskedastisity, and normality tests. Hypotheses were exercised in two stages. The first stage, the researchers used descriptive statistics to describe frequency, standard deviation, mean, median, and modus of the data. The second stage, researchers analyzed the influence of independent variables on dependent variable partially using T-test. Finally, the researchers used F-test to examine the impact of independent variables on dependent variable simultaneously.

\section{Findings}

\subsection{Descriptive Statistics}

Table 4.1 presents the demographic of the respondents in the Board of Cultural Preservation and Language Office of Ministry of Education and Culture located in Kepulauan Riau, Indonesia. The presentage of male and 
female respondents are almost equal. Female represents $45.5 \%$ of the respondents and male represents $54.5 \%$ of the respondents. The age group most represented in this survey is 46 to 50 years of age (25\%). The largest educational background group is undergraduate $(56.8 \%)$, which is not surprising because for the career development reason, in Indonesia public servants have to increase their education toward undergraduate. However, there are still $4.5 \%$ of the respondents elementary school background. The findings in this study can be generalized for the two institutions under the Ministry of Education and Culture, Riau Archipelago Province but are not representative of total populations of Ministry of Education and Culture in Indonesia.

Table 2. Descriptive anaysis for the demographic background

\begin{tabular}{llll}
\hline $\begin{array}{l}\text { Demographic } \\
\text { Characteristics }\end{array}$ & Items & Frequency & Percentage (\%) \\
\hline Sex & Male & 24 & 54.5 \\
Age & Female & 20 & 45.5 \\
& $26-30$ & 7 & 16.0 \\
& $31-35$ & 8 & 18.1 \\
& $36-40$ & 8 & 18.1 \\
& $41-45$ & 3 & 6.8 \\
Educational Background & $46-50$ & 11 & 25.0 \\
& $\geq 50$ & 7 & 16.0 \\
& Elementary School & 2 & 4.5 \\
& Junior High School & 0 & 0 \\
& Senior High School & 11 & 25 \\
& Diploma & 1 & 2.3 \\
& Undergraduate & 24 & 56.8 \\
& Graduate & 5 & 11.3 \\
\hline
\end{tabular}

We assessed the construct of validity (i.e., content, face value, criterion, and construct validity) and reliability (i.e., indicator reliability and internal consistency) for the measurement model (see Table 4.2). According to Giannatasio (2008) indicators of the variable can be validated if $r_{\text {count }} \geq r_{\text {table. }}$. Table 4.2 shows that every item of questions in quetionnaire was valid because $r_{\text {count }} \geq r_{\text {table. }}$. Bowen \& Bowen (1999) suggests that cooficient alpha have to above 0.60 for reliability measurement. Table 4.2 also shows that all variables and indicators were reliable because the value of reliability above 0.60 . 
Table 3. Validity and reliability tests

\begin{tabular}{|c|c|c|c|c|c|}
\hline \multirow{2}{*}{ Constructs } & \multirow{2}{*}{ Item } & \multicolumn{2}{|c|}{ Validity } & \multirow{2}{*}{ Reliability } & \multirow{2}{*}{ Remark } \\
\hline & & $r_{\text {count }}$ & $r_{\text {table }}$ & & \\
\hline \multirow[t]{14}{*}{ Fingerprint (Fi) } & Fi_1 & 0.762 & $>0.297$ & 0.898 & Valid \\
\hline & Fi_2 & 0.879 & $>0.297$ & & Valid \\
\hline & Fi_3 & 0.732 & $>0.297$ & & Valid \\
\hline & Fi_4 & 0.401 & $>0.297$ & & Valid \\
\hline & Fi_5 & 0.721 & $>0.297$ & & Valid \\
\hline & Fi_6 & 0.772 & $>0.297$ & & Valid \\
\hline & Fi_7 & 0.677 & $>0.297$ & & Valid \\
\hline & Fi_8 & 0.652 & $>0.297$ & & Valid \\
\hline & Fi_9 & 0.718 & $>0.297$ & & Valid \\
\hline & Fi_10 & 0.732 & $>0.297$ & & Valid \\
\hline & Fi_11 & 0.837 & $>0.297$ & & Valid \\
\hline & Fi_12 & 0.666 & $>0.297$ & & Valid \\
\hline & Fi_13 & 0.360 & $>0.297$ & & Valid \\
\hline & Fi_14 & 0.724 & $>0.297$ & & Valid \\
\hline \multirow[t]{10}{*}{ Monitoring (Mon) } & Mon_1 & 0.756 & $>0.297$ & 0.873 & Valid \\
\hline & Mon_2 & 0.754 & $>0.297$ & & Valid \\
\hline & Mon_3 & 0.722 & $>0.297$ & & Valid \\
\hline & Mon_4 & 0.654 & $>0.297$ & & Valid \\
\hline & Mon_5 & 0.819 & $>0.297$ & & Valid \\
\hline & Mon_6 & 0.818 & $>0.297$ & & Valid \\
\hline & Mon_7 & 0.752 & $>0.297$ & & Valid \\
\hline & Mon_8 & 0.737 & $>0.297$ & & Valid \\
\hline & Mon_9 & 0.330 & $>0.297$ & & Valid \\
\hline & Mon_10 & 0.770 & $>0.297$ & & Valid \\
\hline \multirow[t]{9}{*}{ Work Discipline (WD) } & WD_1 & 0.581 & $>0.297$ & 0.759 & Valid \\
\hline & WD_2 & 0.687 & $>0.297$ & & Valid \\
\hline & WD_3 & 0.655 & $>0.297$ & & Valid \\
\hline & WD_4 & 0.638 & $>0.297$ & & Valid \\
\hline & WD_5 & 0.417 & $>0.297$ & & Valid \\
\hline & WD_6 & 0.530 & $>0.297$ & & Valid \\
\hline & WD_7 & 0.473 & $>0.297$ & & Valid \\
\hline & WD_8 & 0.611 & $>0.297$ & & Valid \\
\hline & WD_9 & 0.712 & $>0.297$ & & Valid \\
\hline
\end{tabular}

\subsection{Results}

Table 4. ilustrates regression analysis partially between variable fingerprint on work discipline of public servants. Accrording to Alm (1999) hypotheses are tested regarding significant value (p-value), if the significant value resulted from the measurement is under 0.05 , so the hypotheses are accepted. However, if the significant value resulted from the count is more than 0.05 , thus hypotheses are rejected. From Table 4.3 , it can be seen that the result of significance of fingerprint is 0.686 and monitoring is 0.000 . Its mean that fingerprint has not significant 
influence on work discipline because the value of significance is $0.686(p \leq 0.05)$. Meanwhile, monitoring has a positive and significant effect on work discipline because the value of significance is $0,00(p \leq 0.05)$.

Table 4. Regression analysis partially

Coefficientsa

\begin{tabular}{|c|c|c|c|c|c|}
\hline \multirow[t]{2}{*}{ Model } & \multicolumn{2}{|c|}{$\begin{array}{l}\text { Unstandardized } \\
\text { Coefficients }\end{array}$} & \multirow{2}{*}{$\begin{array}{l}\text { Standardized } \\
\text { Coefficients } \\
\text { Beta }\end{array}$} & \multirow[t]{2}{*}{ T } & \multirow[t]{2}{*}{ Sig. } \\
\hline & B & Std. Error & & & \\
\hline (Constant) & 17,192 & 5,238 & & 3,282 & .002 \\
\hline $\begin{array}{l}\text { Fingerprint } \\
\text { Attendace }\end{array}$ & .024 &, 060 &, 054 &, 407 & .686 \\
\hline Monitoring & .447 & .111 & .532 & 4,022 &, 000 \\
\hline
\end{tabular}

Table 5. shows the regression analysis of fingerprint and monitoring on work discipline simultaneously. For this purpose, F-test are choosen to analyze the influence of fingerprint and monitoring simultaneously on work discipline. Statistical result presents the value of Fcount is 8.474 and significance level of $5 \%(p \leq 0.05)$. Its mean that the value of significance is lower than 0.05 . The analysis indicates fingerprint and monitoring have significant effect on work discipline of public servants.

Table 5. Regression analysis simultaneously

\begin{tabular}{|c|c|c|c|c|c|}
\hline \multicolumn{6}{|c|}{ ANOVAA $^{A}$} \\
\hline Model & $\begin{array}{l}\text { Sum of } \\
\text { Squares }\end{array}$ & Df & Mean Square & $\mathrm{F}$ & Sig. \\
\hline $\begin{array}{l}\text { Regression } \\
\text { Residual } \\
\text { Total }\end{array}$ & $\begin{array}{l}148,327 \\
358,832 \\
507,159\end{array}$ & $\begin{array}{r}2 \\
41 \\
43\end{array}$ & $\begin{array}{r}74,163 \\
8,752\end{array}$ & 8,474 &, $001^{\mathrm{b}}$ \\
\hline
\end{tabular}

Table 6. indicates the cooficient determinance of independent variables on dependent variable. The cooficient determinance is the value indicating the value of variations between dependent and independent variables. The cooficient determinance is used to appraisal the value of independent variables on dependent variable. The value of cooficient determinance is depended on the value of adjusted R-square (see Table 4.5). The result of regression reveals cooficient determinance (adjusted R2) is 0.258 . Its mean $25.8 \%$ of work discipline is affected by fingerprint and monitoring of supervisors. Meanwhile the rest of $74.2 \%$ is effected by other variables which is not traced in this study.

Table 6.Cooficient determinance

\begin{tabular}{|c|c|c|c|c|}
\hline Model & $\mathbf{R}$ & $R$ Square & $\begin{array}{c}\text { Adjusted } \mathrm{R} \\
\text { Square }\end{array}$ & $\begin{array}{l}\text { Std. Error of } \\
\text { the Estimate }\end{array}$ \\
\hline 7 & $.541 a$ &, 292 &, 258 & 2,958 \\
\hline
\end{tabular}

\subsection{Discussion}

Indonesian public sector has experienced significant change in recent years under the bureaucratic reform movement. The real action from the movement is adopting the information and technology vehicles supporting public organizations. One of the technology adopted is fingerprint. The purpose of this study is to investigate the influence of fingerprint and monitoring on work discipline of public servants partially in the Board of Cultural Preservation and Language Office of Ministry of Education and Culture, Riau Archipelago. This study also performs the effect of fingerprint and monitoring on work discipline simultaneously.

First, we tested the hypothesis of whether fingerprint has a positive and significant influence on work discipline. The results show that fingerprint does not positively and significant affect on work discipline of public servants and hypothesis H1 is rejected. Our results suggest that policy makers should review the policy of using 
fingerprint to determine the discipline of public servants. As such, our findings are not consistent with regression analysis from previous studies investigating the impact of fingerprint on work discipline of public servants in Indonesia (Asmira, 2016; Anggara, 2016)

The second hypothesis $(\mathrm{H} 2)$ proposed that monitoring by supervisors has a positive impact on work discipline of public servants in Ministry of Education and Culture. The results indicate that the hypothesis is supported by the data. Our study presents empirical evidence that supports the shared view in workplace literature that monitoring can improve work discipline of public servants (Edwards \& Scullion, 1982; de Jong \& Hartog, 2007; Thurau \& Wald, 2009). In this study, monitoring means planning the standards and rules, determining implementation of activity, comparing work with routine standard, and correcting action. Based on our findings, it appears that monitoring led public servants to establish a stronger work discipline in Indonesian public servant.

The third hypothesis $(\mathrm{H} 3)$ proposed that fingerprint and monitoring has a positive and significant effect on work discipline of public servants in the Ministry of Education and Culture. The results show that fingerprint and monitoring have a positive and significant influence on work discipline, hypothesis $\mathrm{H} 3$ is accepted. The findings support the study of Popp \& Belohlav (1982) evidence that absence and monitoring impact on work discipline of solid waste collection drivers and helpers for the City of Cincinnati Waste Collection Division. We believe that if the government increase the system of presence and monitoring by every supervisor in each hierarchy in public organizations, it will improve work discipline of public servants. Thus, fingerprint through mechanism, such as functionality, reliability, usability, and efficiency can improve work discipline. Monitoring requirement through planning the standards and rules, determining implementation of activity, comparing work with routine standard, and correcting action can also increase the discipline of public servants. When public servants have compatible fingerprint and monitoring, it will encourage them to discipline with their job.

The findings of this study should be understanded with caution due to empirical design considerations. First, this study only investigates public servants in the organizations under Ministry of Education and Culture, Riau Archipelago, namely the Board of Cultural Preservation and Language Office, and thus, results are not representative of the entire Indonesian public servants. Second, our sample size was not sufficient to disaggregate the analysis in order to identify the masking discrepancies between male and female public servants. Finally, this study uses a survey and regression design analysis only, which makes it difficult to determine the influence accurately.

It is important also to note that the response of the current study was $25.8 \%$. The rate is too low in determining the influence of independent variables on dependent variable. The rate was caused by the problem of administered questionnaires. Researcher left the questionnaires to the front office and did not interview of respondents face-to-face. The process can generate bias and subjectiveness of the data collected because the questionnaires are full filled by the respondents without researcher presence.

\section{Conclusion}

This study was designed to address a theoretical gap in human resource management of Indonesian public sector regarding investigating the influence of fingerprint and monitoring on work discipline. Additionally, regression analysis was performed to examine whether fingerprint and monitoring have a positive and significant impact on work discipline of public servants, both partially and simultanelously. The findings of this study suggest that partially, fingerprint has not significant effect on work discipline. Meanwhile, monitoring has positive and significant influence on work discipline. The last findings of this study indicates that fingerprint and monitoring have a significant influence on work discipline of public servants. Thus, fingerprint is not to determine the discipline of public servants, as a preposition believed by policy makers in Indonesia. Overall, the findings suggest that policy intervention have to cover by managers of public institution to review the use of fingerprint and they should improve the monitoring of their subordinates.

This study has several theoretical implications. Theoretically, this tudy is the first in the human resources management literature to develop and verify a theoretical framework for the influence among fingerprint, monitoring, and work discipline. This study offers a more thorough understanding of what drives the level of discipline among public servants in Indonesia. Previous studies have clearly indicated the direct positive effect of fingerprint on work discipline. However, this study reveals that fingerprint actually has not positive and significant impact on work discipline. The findings rejects some prior studies related fingerprint and work discipline. Second, this study also analyzes the influence of monitoring by supervisors on work discipline of public servants. However, prior studies lack a deeper understanding on the variable. Third, this study developed and carried out field testing of an instrument for measuring three constructs, i.e., fingerprint, monitoring, and work discipline. Fourth, this study achieved aforementioned theoretical constributions in human resource 
management of public sector in an understudied Indonesian context.

This study offers insight for policy makers to review the implementing fingerprint in Indonesian public sector. Policy makers need to consider various presence systems beside fingerprint, such as retrinal, card system attendance, etc. This study are also fruitfull for managers in public organizations to implement effective monitoring for increasing work discipline of public servants. Managers should develop many style and approach to implement monitoring system of public servants. Actually, managers do not too rigid and regulation-oriented in monitoring of employees. Sometimes, managers should use smooth style and other time manager can be strickly to ensure the discipline of employees.

\section{References}

Al-Qutaish, R. E. (2010). Quality models in software engineering literature: an analytical and comparative study. Journal of American Science, 6(3), 166-175.

Alm, L. R. (1999). Linear correlation and regression. In G. J. Miller \& M. L. Whicker (Eds.), Handbook of research methods in public administration (pp. 249-276). New York: Marcel Dekker.

Anggara, S. (2016). The implementation of fingerprint policy to discipline civil servants in the Faculty of Social and Political UIN Sunan Gunung Djati Bandung. The Social Sciences, 11(15), 3702-3706.

Asmira. (2016). Efektivitas penerapan absensi (fingerprint) dalam meningkatkan disiplin kerja pegawai di Kecamatan Anggana Kabupaten Kutai Kartanegara [Effectiveness of fingerprint absence improving work discipline of employees in Anggana District, Kutai Kartanegara Regency]. eJournal Ilmu Pemerintahan, 4(3), 1009-1022.

Belohlav, J. A. (1985). A Comparative view of employee disciplinary practices. Public Personnel Management, 14(3), 245-251.

Bevan, N. (1995). Measuring usability as quality of use. Software Quality Journal, 4(2), 115-130. https://doi.org/10.1007/BF00402715

Bevan, N. (1999). Quality in use: meeting user needs for quality. Journal of Systems and Software, 49(1), 89-96. https://doi.org/10.1016/S0164-1212(99)00070-9

Bevan, N., \& Azuma, M. (1997). Quality in use: incorporating human factors into the software engineering lifecycle. In Proceedings of IEEE International Symposium on Software Engineering Standards (Vol. 9, pp. 169-179). Institute of Electrical and Electronics Engineers. https://doi.org/10.1109/SESS.1997.595963

Beyer, J. M., \& Trice, H. M. (1984). A field study of the use and perceived effects of discipline in controlling work performance. Academy of Management Journal, 27(4), 743-764. https://doi.org/10.2307/255876

Bowen, W. M., \& Bowen, C.-C. (1999). Typologies, indexing, content analysis, meta-analysis, and scaling as measurement techniques. In G. J. Miller \& M. L. Whicker (Eds.), Handbook of research methods in public administration (pp. 51-86). New York: Marcel Dekker.

Boyne, G. A. (2002). Public and private management: what's the difference? Journal of Management Studies, 39(1), 97-122. https://doi.org/10.1111/1467-6486.00284

Bryant, A. W. (1984). Replacing punitive discipline with a positive approach. Personnel Administrator, 29(2), 79-87.

Campbell, D. N., Fleming, R. L., \& Grote, R. C. (1985). Discipline without punishment-at last! Harvard Business Review, 63(4), 162-178.

Daft, R. L. (2008). Management, eighth edition. New York: Thomson.

de Jong, J. P. J., \& Hartog, D. N. Den. (2007). How leaders influence employees ' innovative behaviour. European Journal of Innovation Management, 10(1), 41-64. https://doi.org/10.1108/14601060710720546

Drucker, P., \& Maciariello, J. A. (2008). Management, revised edition. New York: Harper Collins.

Edward III, G. C. (1980). Implementing public policy. Washington DC: Congressional Quarterly Press.

Edwards, P. K., \& Scullion, H. (1982). Deviancy theory and industrial praxis: a study of discipline and social control in an industrial setting. Sociology, 16(3), 322-340. https://doi.org/10.1177/0038038582016003001

Franklin, A. L., \& Pagan, J. F. (2006). Organization culture as an explanation for employee discipline practices. Review of Public Personnel Administration, 26(1), 52-73. https://doi.org/10.1177/0734371X05277335

Giannatasio, N. A. (2008). Threats to validity in research designs. In Y. Kaifeng \& G. J. Miller (Eds.), Handbook 
of research methods in public administration (pp. 109-128). Boca Raton, FL: CRC Press.

Giné, X., et al. (2012). Use of biometric technology in developing countries. In R. Cull, A. Demirgüç-Kunt, \& J. Morduch (Eds.), Banking the world: empirical foundations of financial inclusion (pp. 296-322). Cheltenham, UK: Edward Elgar.

Grote, D. (2006). Discipline without punishment: the proven strategy that turns problem employees into superior performers, second edition. New York: Amacom.

Grote, R. C., \& Harvey, E. L. (1983). Discipline without punishment. New York: McGraw Hill.

Guffey, C. J., \& Helms, M. M. (2001). Effective employee discipline: a case of the Internal Revenue Service. Public Personnel Management, 30(1), 111-127. https://doi.org/10.1177/009102600103000110

Harrald, J. R. (2006). Agility and discipline: critical success factors for disaster response. Annals of the American Academy of Political and Social Science, 604(1), 256-272. https://doi.org/10.1177/0002716205285404

Hays, S. W. (1995). Employee discipline and removal: coping with job security. In S. W. Hays, \& R. Kearney (Eds.), Public personnel administration: problems and prospects, third edition (pp. 145-161). Englewood Cliffs, NJ: Prentice Hall.

Hays, S. W. (1996). The "state of the discipline" in public personnel administration. Public Administration Quarterly, 20(3), 285-304.

Hays, S. W. (2008). Discipline and dismissal. In E. M. Berman, \& J. Rabin (Eds.), Encyclopedia of public administration and public policy, second edition (pp. 555-557). Boca Raton, FL: Taylor \& Francis.

Hendrotriatmoko, A., Hadi, S., \& Dachlan, H. S. (2014). Penggunaan metode Viola-Jones dan Algoritma Eigen Eyes dalam sistem hehadiran pegawai [The use of Viola-Jones and Algoritma Eigen Eyes Methods in the presence of employee system]. Jurnal EECCIS, 8(1), 41-46.

Huberman, J. (1964). Discipline without punishment. Harvard Business Review, 42(4), $62-68$.

Jain, A. K., Hong, L., Pankanti, S., \& Bolle, R. (1997). An identity-authentication system using fingerprints. In Proceedings of the IEEE (Vol. 85, pp. 1365-1388). https://doi.org/10.1109/5.628674

Kettl, D. F. (2000). The global public management revolution. Washington, D.C.: Brookings Institution Press.

Lachman, R. (1985). Public and private sector differences: CEOs' perceptions of their role environments. Academy of Management Journal, 28(3), 671-680. https://doi.org/10.2307/256122

Leavitt, W. M., \& Johnson, G. (1998). Employee discipline and the post-bureaucratic public organization: a challenge in the change process. Review of Public Personnel Administration, 18(2), 73-81. https://doi.org/10.1177/0734371X9801800206

Mangkunegara, A. P., \& Waris, A. (2015). Effect of training, competence and discipline on employee performance in company: case study in PT Bangun Asuransi Askrida. In Procedia - Social and Behavioral Sciences (Vol. 211, pp. 1240-1251). https://doi.org/10.1016/j.sbspro.2015.11.165

McKenzie, P. et al. (2014). Study on teacher absenteeism in Indonesia 2014. Jakarta.

Meier, K. J., \& O'Toole, L. J. (2011). Comparing public and private management: Theoretical expectations. Journal of Public Administration Research and Theory, 21(Suppl. 3), 283-299. https://doi.org/10.1093/jopart/mur027

Murray, M. A. (1975). Comparing public and private management: an exploratory Essay. Public Administration Review, 35(4), 364-371. https://doi.org/10.2307/974538

Osborne, D., \& Gaebler, T. (1992). Reinventing government: how the entrepreneurial spirit is transforming government. Reading, MA: Adison-Wesley.

Popp, P. O., \& Belohlav, J. A. (1982). Absenteeism in a low status work environment. Academy of Management Journal, 25(3), 677-683. https://doi.org/10.2307/256090

Rainey, H. G. (2003). Understanding and managing public organizations (3rd ed.). San Fransisco: Jossey-Bass.

Rainey, H. G., Backoff, R. W., \& Levine, C. H. (1976). Comparing public and private organizations. Public Administration Review, 36(2), 233-244. https://doi.org/10.2307/975145

Rainey, H. G., \& Bozeman, B. (2000). Comparing public and private organizations: empirical research and the power of the a priori. Journal of Public Administration Research and Theory, 10(2), 447-469. https://doi.org/10.1093/oxfordjournals.jpart.a024276 
Redeker, J. R. (1989). Employee discipline: policies and practices. Washington, DC: Bureau of National Affairs.

Riccucci, N. M., \& Wheeler, G. R. (1987). Positive employee performance: an innovative approach to employee discipline. Review of Public Personnel Administration, 8(1), 49-63. https://doi.org/10.1177/0734371X8700800104

Robbins, S., \& Coulter, M. (2012). Management (11th ed.). Boston, MA: Prentice Hall.

Robbins, S. P., \& Judge, T. A. (1993). Organization behaviour. London: Prentice Hall.

Rosen, B., \& Jerdee, T. H. (1974). Factors influencing disciplinary judgements. Journal of Applied Psychology, 59(3), 327-331. https://doi.org/10.1037/h0036762

Saraswat, C., \& Kumar, A. (2010). An efficient automatic attendance system using fingerprint verification technique. International Journal of Computer Science and Information Security, 2(2), 264-269.

Senge, P. M. (1997). The fifth discipline. Measuring Business Excellence, 1(3), 46-51. https://doi.org/10.1108/eb025496

Shoewu, O., \& Idowu, O. A. (2012). Development of attendance management system using biometrics. Pacific Journal of Science and Technology, 13(1), 300-307.

Singh, G., et al. (2010). E-governance for improved public service delivery in India, Ethiopia and Fiji. International Journal of Public Sector Management, 23(3), 254-275. https://doi.org/10.1108/09513551011032473

Sofyan, M., et al. (2016). The effect of career development and working discipline towards working satisfaction and employee performance in the regional office of Ministry of Religious Affairs in South Sulawesi. International Journal of Scientific and Technology Research, 5(3), 51-57.

Soss, J., Fording, R., \& Schram, S. F. (2011). The organization of discipline: from performance management to perversity and punishment. Journal of Public Administration Research and Theory, 21(Supplement 2), 203232. https://doi.org/10.1093/jopart/muq095

Stoner, J. A. F., Freeman, R. E., \& Gilbert, D. R. (1995). Management (6th ed.). New Jersey: Prentice Hall.

Taylor, F. W. (2003). Scientific management. London: Routledge.

Terry, G. R., \& Franklin, S. G. (1968). Principles of management (6th ed.). Illinois: RD Irwin.

Thaief, I., Baharuddin, A., \& Idrus, M. S. (2015). Effect of training, compensation and work discipline against employee job performance: studies in the office of PT PLN (Persero) service area and network. Review of European Studies, 7(11), 23-33. https://doi.org/10.5539/res.v7n11p23

Thurau, L. H., \& Wald, J. (2009). Controlling partners: when law enforcement meets discipline in public schools. New York Law School Law Review, 54(10), 977-1020.

Wayman, J., et al. (2005). An introduction to Biometric authentication systems. In J. Wayman, A. Jain, D. Maltoni, \& D. Maio (Eds.), Biometric systems: technology, desain and performance evaluation (pp. 1-20). London: Springer. https://doi.org/10.1007/1-84628-064-8_1

Yudiatmaja, W. E., \& Yoserizal. (2010). Strategi Pemerintah Provinsi Sumatera Barat dalam mengembangkan e-government sebagai upaya peningkatan kualitas pelayanan publik [Strategy of the Government of West Sumatera developing e-government as a effort to improve public service]. Jurnal Ilmu Administrasi Negara, 10(1), 89-100.

Yukl, G. (2010). Leadership in organizations (7th ed.). New Jersey: Pearson.

\section{Copyrights}

Copyright for this article is retained by the author(s), with first publication rights granted to the journal.

This is an open-access article distributed under the terms and conditions of the Creative Commons Attribution license (http://creativecommons.org/licenses/by/4.0/). 